\title{
중 \\ Strategi Komunikasi Persuasi untuk Pencegahan Aksi Bullying di SMP Negeri 85 Jakarta
}

\author{
http://dx.doi.org/10.25008/wartaiski.v4i1.102
}

\author{
Veronika Trimardhani ${ }^{1}$, Dewi Rachmawati ${ }^{*}$, Yulma $^{3}$ \\ ${ }^{1,2,3}$ Fakultas Komunikasi, Institut Komunikasi \& Bisnis LSPR \\ J1 K.H. Mas Mansyur Kav 35, Jakarta 12310 - Indonesia \\ *e-mail korespondensi: dewi.r@1spr.edu
}

Submitted: 11/03/2021, Revised: 30/05/2021, Accepted: 17/06/2021

Accredited by Kemristekdikti No. 30/E/KPT/2019

\begin{abstract}
Bullying is a hot topic discussed in Indonesia, especially bullying in school environment (school bullying). This research is motivated by the many cases of bullying that occur, especially at the junior high school (SMP) level. In general, at this level, adolescents are confused in showing their existence. This confusion often makes them want to outperform their peers. This study aims to: first, know how the strategy of persuasion of the bullying prevention program provided by the school to junior high school adolescents. And the second aim to determine the responses of junior high school students who receive bullying prevention programs. This study uses persuasion communication theory as the focus of research in preventing bullying. This study used qualitative research methods. The data collection technique was carried out in two ways, Focus Group Discussion with several sources, the principal, the vice principal of student affairs, counseling teachers and teachers who are Quality Control at the school. Furthermore, interviews were also conducted with two students of SMPN 85 Pondok Labu Jakarta. The results showed that the school's efforts to persuade students were successful. This can be demonstrated by the resource persons' efforts to influence students in bullying prevention programs. In addition, the success of the program was also stated to have a positive impact by students, where students became aware of and were willing to take bullying prevention action voluntarily and with mutual empathy for others.
\end{abstract}

Keywords: Bullying, school, persuasion communication, prevention programs, students of junior hich school,

\begin{abstract}
Abstrak
Bullying menjadi isu yang hangat dibicarakan di lingkungan sekolah (school bullying). Penelitian ini dilatarbelakangi banyaknya kasus bullying yang terjadi, terutama pada tingkat Sekolah Menengah Pertama (SMP). Pada umumnya di tingkat ini remaja sedang kebingungan dalam memperlihatkan eksistensinya. Kebingungan tersebut tidak jarang menjadikan mereka ingin tampil melebihi teman sebayanya. Penelitian ini bertujuan untuk (1) mengetahui bagaimana stategi persuasi program pencegahan bulliying yang diberikan pihak sekolah terhadap remaja SMP; (2) untuk mengetahui tanggapan siswa SMP atas program pencegahan bullying. Penelitian ini menggunakan teori komunikasi persuasi sebagai fokus penelitian dalam pencegahan bullying. Pada penelitian ini digunakan metode penelitian kualitatif. Teknik pengumpulan data dilakukan dengan dua cara yaitu Focus Group Discussion terhadap beberapa narasumber yaitu kepala sekolah, Wakil kepala sekolah bidang kesiswaan, guru BK dan guru yang merupakan Quality Control d isekolah tersebut. Selanjutnya dilakukan wawancara terhadap dua orang siswa SMPN 85 Pondok Labu Jakarta. Hasil penelitian menunjukkan, upaya sekolah untuk mempersuasi para siswa dapat dikatakan berhasil. Hal ini ditunjukkan dengan upaya sekolah untuk mempengaruhi para siswa dalam program pencegahan bullying. Selain itu keberhasilan program tersebut juga dinyatakan berdampak positif oleh siswa, di mana para siswa menjadi paham dan bersedia melakukan tindakan pencegahan bullying dengan suka rela dan saling empati terhadap sesama.
\end{abstract}

Kata Kunci: Bullying, sekolah, komunikasi persuasi, program pencegahan, pelajar SMP. 


\section{PENDAHULUAN}

Bullying atau perundungan menjadi topik yang banyak dibicarakan terkait remaja. Bullying dapat terjadi di manapun dan kapanpun. Sekolah menjadi salah satu tempat terjadinya bullying. Menurut Olweus dalam Prasetyo (2011), bullying berasal dari kata bully yang berarti menggertak dan mengganggu orang yang lebih lemah. Istillah bullying digunakan untuk menunjuk perilaku agresif seseorang atau sekelompok orang yang dilakukan secara berulang-ulang terhadap orang atau sekelompok orang lain yang lebih lemah untuk menyakiti korban secara fisik maupun mental. Bullying bisa berupa kekerasan bentuk fisik, seperti menampar, memukul, menganiaya, menciderai, maupun tindakan verbal, misalnya mengejek, mengolok-olok, memaki, serta tindakan mental atau psikis, seperti memalak, mengancam, mengintimidasi, mengucilkan.

Angka bullying di Indonesia cukup tinggi meski data akuratnya belum diketahui pasti. Setidaknya sebanyak $40 \%$ remaja telah diintimidasi di sekolah dan 32\% melaporkan bahwa mereka menjadi korban kekerasan fisik. Survei Kementerian Sosial RI tahun 2013 menunjukkan, satu dari dua remaja pria $(47,45 \%)$ dan satu dari tiga remaja wanita $(35,05 \%)$ dilaporkan mengalami intimidasi. Data lebih lanjut Survei Kesehatan Siswa berbasis Global School-based Student Health Survey tahun 2015 menunjukkan, $24,1 \%$ remaja pria dan $17,4 \%$ remaja wanita mengalami intimidasi.

Sementara itu hingga Juni 2017 Kementerian Sosial telah menerima laporan 976 kasus dengan 117 kasus bullying. Komisi Perlindungan Anak Indonesia (KPAI) menyebutkan, adanya peningkatan kasus bullying di kalangan pelajar. Menurut data KPAI, sejak 2011 hingga 2016, KPAI telah menemukan 253 kasus bullying terdiri dari 122 anak menjadi korban dan 131 jadi pelaku (Efendi, 2019).

Bullying seringkali terjadi di sekolah ataupun di perguruan tinggi. Tindakan memaksakan kehendak seperti yang terjadi di SD di Sungai Ulak, Kabupaten Merangin, Propinsi Jambi, ketika seorang pelajar di-bully oleh teman temannya karena tidak mau memberikan contekan, sering terjadi. Akibatnya, korban yang dianiaya teman-temannya mengalami trauma, dan depresi berat (Jefrizal, 2020). "Jika bertemu orang yang memakai seragam dinas, dia teriak-teriak, apalagi melihat orang memakai pakaian sekolah. Anak saya ditarik rambutnya, dibenturkan kepalanya ke dinding oleh temannya, membuat anak saya trauma," kata orang tua korban bullying (Santoso, 2020).

Di tempat berbeda, seorang siswi kelas VII Sekolah Menengah Pertama (SMP) Negeri di Kota Kediri mengalami perundungan. Akibatnya, siswi itu depresi dan ingin bunuh diri. Peristiwa tersebut bermula saat siswa itu mengikuti kegiatan ekstrakurikuler, lalu dia meminta izin pulang. Salah satu guru menegurnya dan mengatakan tidak akan memberikan nilai karena dia sering membolos.

Siswa itu juga mengalami perundungan dari teman-temannya. Walaupun permasalahan sudah diselesaikan secara kekeluargaan antara pihak sekolah dan keluarga korban, namun ini menunjukkan bahwa bullying tidak hanya dilakukan oleh teman teman sebaya di sekolah namun juga dapat dilakukan oleh guru di sekolah (Iswinarno, 2020).

Apabila kejadian bullying tidak segera diselesaikan, maka dapat mengakibatkan kejadian yang tidak diinginkan, misalnya bunuh diri. Hal ini terjadi di Johor, Malaysia, seperti diberitakan suara.com. Seorang remaja berusia 17 tahun melompat dari lantai empat sebuah mal. Anak itu mengakhiri hidupnya karena menjadi korban bullying. Dua anak yang melakukan bullying datang ke pemakanan untuk meminta maaf atas perbuatan mereka (Gunadha \& Aditya, 2020)

Dari peristiwa-peristiwa di atas, dapat disimpulkan bahwa bullying bisa dilakukan oleh siapa saja, mulai dari teman sekelas, kakak kelas bahkan guru. Efek bullying terhadap korban, tidak dapat disebut ringan. Korban bullying menderita fisik dan psikis, membuat korban menjadi murung, trauma bahkan melakukan tindakan bunuh diri.

Penelitian tentang bullying ini dilakukan di SMP Negeri 85 Pondok Labu. Alasan dipilihnya sekolah itu karena SMP Negeri 85 merupakan salah satu sekolah terbaik di Jakarta Selatan. Sebagai sekolah terbaik, menarik untuk mengetahui apakah di sana terjadi bullying? Kalau ya, bagaimana sampai bullying bisa terjadi dan mengapa anak anak melakukan bullying? Faktor apa yang menyebabkan terjadinya bullying, dan strategi apa yang diambil pihak sekolah mengatasi bullying.

Tujuan penelitian ini adalah untuk mengetahui bagaimana stategi persuasi program pencegahan bullying pihak sekolah terhadap remaja SMP Negeri 85 Pondok Labu. Selain itu juga untuk mengetahui tanggapan para siswa yang mendapat program pencegahan bullying. 


\section{KERANGKA TEORI}

Komunikasi persuasif diartikan sebagai suatu bentuk komunikasi yang dilakukan sebagai ajakan atau bujukan agar seseorang mau bertindak sesuai keinginan komunikator (Barata, 2003). Menurut De Vito (2011), usaha melakukan persuasi adalah memusatkan perhatian pada upaya mengubah atau memperkuat sikap khalayak, atau upaya mengajak mereka bertindak dengan cara tertentu. Menurut Rakhmat (2008), persuasi diartikan sebagai "suatu proses untuk mempengaruhi pendapat, sikap dan tindakan seseorang dengan menggunakan manipulasi psikologis sehingga orang tersebut bertindak seperti atas kehendaknya sendiri".

Persuasi juga dipahami sebagai usaha merubah sikap melalui penggunaan pesan dan berfokus pada karakteristik komunikator dan pendengar. Menurut Olzon dan Zanna (dalam Severin \& Tankard, 2007), persuasi didefinisikan sebagai "perubahan sikap akibat paparan informasi dari orang lain".

Tujuan dari Komunikasi Persuasif menurut De Vito (dalam Riyanto \& Mahfud, 2012) ada dua yaitu: (1) untuk mengubah atau menguatkan keyakinan (believe) dan sikap (attitude) pendengarnya, (2) untuk mendorong pendengar melakukan sesuatu atau memiliki tingkah laku (behaviour) tertentu seperti yang diharapkan.

Berdasarkan pemaparan tersebut, komunikasi persuasif haruslah efektif, berarti harus menimbulkan efek. Menurut Applbaum (dalam Efendi, 2019) efek adalah apa yang terjadi pada komunikan merupakan akibat dari dampak stimuli pesan. Dalam komunikasi persuasif, efek merupakan dampak dalam perubahan sikap, opini dan tingkah laku yang timbul dari kesadaran komunikan, sebab komunikasi persuasif berbeda dengan komunikasi informatif, berbeda pula dengan komunikasi koersif.

Unsur-unsur dalam komunikasi persuasif menurut Sumirat \& Suryana (2014) adalah: Persuader, Persuadee, Persepsi, Pesan Persuasif dan Saluran Persuasif. Persuader adalah orang dan atau sekelompok orang yang menyampaikan pesan dengan tujuan untuk mempengaruhi sikap, pendapat dan perilaku orang lain, baik secara verbal maupun nonverbal. Persuadee adalah orang dan atau kelompok orang yang menjadi tujuan pesan itu disampaikan atau disalurkan oleh persuader/komunikator baik secara verbal maupun nonverbal.

Persepsi persuadee terhadap persuader dan pesan yang disampaikannya akan menentukan efektif tidaknya komunikasi persuasif. Persepsi menurut Mar'at (dalam Sumirat \& Suryana, 2014) merupakan proses pengamatan seseorang dari komponen kognisi. Persepsi dipengaruhi oleh faktor-faktor, antara lain pengalaman, proses belajar, cakrawala, dan pengetahuan seseorang. Sedangkan Pesan Persuasif, menurut Littlejohn (dalam Ritonga, 2005adalah usaha sadar untuk mengubah pikiran dan tindakan dengan memanipulasi motif-motif ke arah tujuan yang telah ditetapkan.

Makna memanipulasi dalam pernyataan bukanlah mengurangi atau menambah fakta sesuai konteksnya, tetapi memanfaatkan faktum faktum yang berkaitan dengan motif-motif khalayak sasaran, sehingga tergerak untuk mengikuti maksud pesan yang disampaikan kepadanya. Sedangkan Saluran merupakan perantara ketika seorang persuadee mengoperkan kembali pesan dari sumber awal untuk tujuan akhir. Saluran (channel) digunakan oleh persuader untuk berkomunikasi dengan berbagai orang secara formal maupun nonformal, tatap muka (face to face communication) ataupun bermedia (mediated communication).

Umpan Balik dan Eeek dalam komunikasi menurut Sastropoetro (dalam Sumirat \& Suryana, 2014) adalah jawaban atau reaksi yang datang dari komunikan atau datang dari pesan itu sendiri. Umpan balik terdiri dari umpan balik internal dan umpan balik eksternal. Umpan balik internal adalah reaksi komunikator atas pesan yang disampaikannya. Umpan balik internal bersifat koreksi atas pesan yang terlanjur diucapkan. Sedangkan umpan balik eksternal adalah reaksi yang datang dari komunikan karena pesan yang disampaikan komunikator tidak dipahami atau tidak sesuai dengan keinginannya.

Efek adalah perubahan yang terjadi pada diri komunikan sebagai akibat dari diterimanya pesan melalui proses komunikasi (Sastropoetro dalam Sumirat \& Suryana, 2014). Perubahan yang terjadi bisa berupa perubahan sikap, pendapat, pandangan dan tingkah laku. Dalam komunikasi persuasif, terjadinya perubahan dalam aspek sikap, pendapat maupun perilaku pada diri persuadee merupakan tujuan utama. Inilah letak pokok yang membedakan komunikasi persuasif dengan komunikasi lainnya.

Menurut De Vito (2011), dalam Komunikasi Persuasif terdapat empat prinsip utama. Pertama, adalah Prinsip Pemaparan Selektif. Prinsip ini menerangkan bahwa (1) pendengar akan mencari informasi secara aktif yang mendukung opini, nilai, keputusan, perilaku, dan motivasi mereka; (2) pendengar akan secara aktif menghindari informasi yang bertentangan dengan opini, nilai, keputusan, 
perilaku, dan motivasi mereka. Ketika proses meyakinkan sasaran persuasi akan dilangsungkan, maka pemaparan selektif akan terjadi.

Prinsip Kedua adalah Prinsip Partisipasi Khalayak. Khalayak merupakan sasaran persuasi. Aktivitas komunikasi persuasif ini akan lebih efektif apabila khalayak turut berpartisipasi dalam proses komunikasi. Persuasi bersifat transaksional dengan pembicara dan pendengar saling terlibat. Suatu proses persuasi dikatakan berhasil apabila khalayak berpartisipasi secara aktif di dalamnya.

Prinsip ketiga adalah Prinsip Inokulasi. Prinsip ini menjelaskan tentang sasaran persuasi yang terinokulasi, atau sasaran yang telah mengetahui posisi persuader dan telah menyiapkan senjata berupa argumen untuk menentangnya. Sehingga pada posisi ini, seorang persuader perlu melakukan persiapan, seperti mempersiapkan argumen dalam proses komunikasi yang akan dilakukan.

Prinsip keempat adalah Prinsip Besaran Perubahan. Prinsip ini mengatakan, semakin besar dan semakin penting perubahan yang diinginkan oleh persuader, maka semakin besar tantangan dan tugas untuk mencapai tujuan persuasi. Semakin besar perubahan yang diinginkan, semakin banyak pula waktu yang dibutuhkan untuk perubahan tersebut, sehingga persuasi diarahkan untuk melakukan perubahan sedikit demi sedikit terlebih dahulu.

Terdapat beberapa definisi yang beragam mengenai bullying. Menurut Lestari (2016), bullying berarti adanya ancaman yang dilakukan seseorang terhadap orang lain yang menimbulkan gangguan fisik atau psikis maupun keduanya. Ken Rigby (2008), mengatakan "Bullying is the systematic abuse of power in interpersonal relationship". Bullying adalah suatu bentuk penyalahgunaan kekuatan atau kekuasaan secara sistematis dalam hubungan antarperorangan. Adapun yang dimaksud dengan "Kekuatan" atau "Kekuasaan" adalah orang-orang yang melakukan tindakan bullying karena memiliki kekuatan dan kewewenangan.

Ken Rigby (2008) menjelaskan berbagai bentuk kekuasaaan yang dimiliki oleh orang-orang yang memiliki kewenangan seperti orang tua, birokrat, guru, politisi, kepala sekolah dan lainnya. Kekuasaan yang mereka miliki tidak membatasi mereka untuk melakukan tindakan bullying. Hampir sama dengan pendapat Ken Rigby, The National Safe Schools Frameworks (2013) mendefinisikan bullying sebagai perilaku verbal, fisik, sosial atau psikologi berbahaya yang dilakukan secara berulang-ulang oleh individu maupun kelompok dengan menyalahgunakan kekuatan atau kekuasaan yang dimilikinya kepada satu orang atau lebih.

Menurut Black dan Jackson (2007), bullying adalah perilaku agresif tipe proaktif yang di dalamnya terdapat aspek kesengajaan untuk mendominasi, menyakiti, atau menyingkirkan. Adanya ketidakseimbangan kekuatan baik secara fisik, usia atau kemampuan kognitif, keterampilan, maupun status sosial, serta dilakukan secara berulang-ulang oleh satu atau beberapa anak terhadap anak lain.

Berdasarkan beberapa definisi di atas, bullying digambarkan sebagai suatu perilaku agresif yang dilandasi intensi untuk secara sengaja mengakibatkan tekanan fisik atau psikologis kepada orang lain yang dilakukan secara berulang-ulang oleh individu atau kelompok dengan menyalahgunakan kekuatan atau kekuasaan yang dimilikinya terhadap individu yang lebih lemah.

Menurut Coloroso (2007), bullying dibagi menjadi tiga jenis. Pertama, Bullying Fisik, merupakan jenis bullying yang paling tampak dan paling dapat diidentifikasi diantara bentuk-bentuk penindasan lainnya, namun kejadian penindasan fisik terhitung kurang dari sepertiga insiden penindasan yang dilaporkan oleh siswa. Jenis penindasan secara fisik antara lain memukul, mencekik, menyikut, meninju, menendang, menggigit, memiting, mencakar, meludahi anak yang ditindas hingga ke posisi menyakitkan, merusak dan menghancurkan pakaian serta barang-barang milik anak yang tertindas. Semakin kuat dan semakin dewasa sang penindas, semakin berbahaya jenis serangan ini.

Kedua, Bullying Verbal yaitu kata-kata yang bisa digunakan sebagai alat mematahkan semangat anak yang menerimanya. Verbal abuse adalah bentuk yang paling umum digunakan baik oleh anak perempuan maupun anak laki-laki. Hal ini dapat terjadi pada orang dewasa dan teman sebaya tanpa terdeteksi. Verbal bullying dapat berupa teriakan dan keriuhan yang terdengar. Hal ini berlangsung cepat tanpa rasa sakit pada pelaku bullying dan sangat menyakitkan target. Jika verbal bullying dimaklumi, maka akan menjadi sesuatu yang normal dan target menjadi dehumanized. Ketika seseorang menjadi dehumanized, maka orang tersebut akan lebih mudah lagi untuk diserang tanpa mendapatkan perlindungan dari orang di sekitar yang mendengarnya.

Verbal bullying dapat berbentuk julukan nama, ejekan, meremehkan, fitnah secara personal, kritik kejam, menghina ras, ucapan yang kasar, dan pernyataan-pernyataan bernuansa ajakan seksual atau pelecehan seksual. Selain itu, penindasan verbal dapat berupa perampasan uang jajan atau barang- 
barang, telepon yang kasar, e-mail yang mengintimidasi, surat-surat kaleng berisi ancaman kekerasan, tuduhan-tuduhan yang tidak benar, kasak-kusuk yang keji, serta gossip.

Ketiga, Bullying Relasional. Bullying tipe ini paling sulit dideteksi. Relasional bullying adalah pengurangan perasaaan sense diri seseorang secara sistematis melalui pengabaian, pengisolasian, pengeluaran, penghindaran. Penghindaran, sebagai suatu perilaku penghilangan, dilakukan bersama rumor adalah sebuah cara yang paling kuat dalam melakukan bullying. Penindasan relasional dapat digunakan untuk mengasingkan atau menolak seorang teman atau secara sengaja ditujukan untuk merusak persahabatan. Perilaku ini mencakup sikap-sikap tersembunyi seperti pandangan yang agresif, lirikan mata, helaan napas, bahu yang bergidik, cibiran, tawa mengejek, dan bahasa tubuh yang kasar.

Menurut Astuti (2008), ada beberapa jenis-jenis bullying, yaitu pertama, fisik: bentuk bullying yang dapat dilihat oleh kasat mata, contohnya menggigit, menarik rambut, memukul, menendang, mengunci dan mengintimidasi korban di ruangan atau dengan mengitari, memelintir, menonjok, mendorong, mencakar, meludahi, mengancam, dan merusak barang korban, penggunaan senjata dan perbuatan kriminal. Kedua, Nonfisik terbagi dalam bentuk verbal dan non-verbal. Contoh bullying verbal adalah panggilan telepon yang meledek, pemalakan, pemerasan, mengancam, atau intimidasi, menghasut, berkata jorok pada korban, berkata menekan, menyebarluaskan kejelekan korban.

Sedangkan contoh bullying nonverbal terbagi menjadi langsung dan tidak langsung. Langsung, contohnya adalah gerakan (tangan, kaki, atau anggota badan lain) kasar atau mengancam, menatap, muka mengancam, menggeram, hentakan, mengancam. Bullying tidak langsung diantaranya adalah manipulasi pertemanan, mengasingkan, tidak mengikutsertakan, mengirim pesan menghasut, curang dan sembunyi-sembunyi

Parsons (2009) membagi bullying menjadi beberapa jenis. Bullying verbal atau tertulis, Bullying fisik dan Bullying sosial. Pertama, bullying verbal atau tertulis yaitu mengata-ngatai seperti menggunakan ejekan yang bermuatan rasis, seksis atau homofobik, ledekan terhadap penampilan fisik, kemampuan, atau status sosial ekonomi, telepon, SMS, email yang berisi ancaman dan manakut-nakuti.

Kedua bullying fisik, contohnya memukul, menendang, menginjak, menyerang, melempar bendabenda, melakukan sentuhan seksual yang tidak diinginkan, mencuri atau merusak benda-benda atau milik pribadi, mengancam dengan senjata, mengancam dengan melakukan kekerasan, melakukan paksaaan. Sedangkan Ketiga adalah bullying sosial seperti merangkai rumor dan gosip, mengucilkan, mempermalukan, atau mencemooh seseorang secara publik, menceritakan informasi pribadi seseorang, termasuk menayangkan gambar atau tulisan pada website, menggunakan pertemanan atau status untuk melakukan paksaaan atau manipulasi perilaku.

Parsons (2009) juga menjelaskan jenis bullying dalam dunia maya (cyberbullying). Cyberbullying meliputi bentuk agresi dalam hubungan dan segala bentuk-bentuk ancaman elektronik dan hal ini terjadi dimana-mana. Pesan-pesan yang tidak beridentitas dalam email, instant messaging, dan ruang chatting memberikan peluang yang besar bagi pelaku bullying kepada korban.

Berdasarkan penjelasan tersebut, bentuk bullying dilakukan secara fisik, psikis maupun relasional. Bullying fisik, seperti menendang, memukul, mendorong, meludahi, bahkan kekerasan yang dilakukan dengan senjata. Sedangkan bullying psikis, seperti memaki, menghina, menuduh, memfitnah, menyoraki, serta mempermalukan di depan umum. Kemudian bullying relasional, seperti menolak, penghindaran, dan pengucilan. Selain itu, juga terdapat bullying yang dilakukan melalui media elektronik dan internet yaitu cyberbullying.

Penyebab bullying menurut Mellor dan Djuwita (dalam Lestari, 2016) adalah: (1) faktor keluarga, sikap orang tua yang berlebihan dalam melindungi anaknya sehingga cenderung mengekang anak, dan pola hidup orang tua yang berantakan (perceraian); (2) faktor teman sebaya, pengaruh lingkungan rumah sangat besar, misalnya anak hidup di lingkungan yang sering terjadi perkelahian atau bermusuhan, berperilaku tidak sesuai norma yang ada, maka anak akan mudah meniru perilaku lingkungan tersebut tanpa rasa bersalah; (3) faktor media massa, modeling atau meniru perilaku "bullying" selain dari kelompok pergaulannya juga tayangan bernuansa kekerasan di internet atau televisi; (4) faktor budaya, kondisi kehidupan sosial terutama di kota-kota besar sudah mengidap penyakit frustasi sosial. Selain itu, sistem kehidupan sosial yang dianut saat ini yaitu adult oriental, selalu mengakomodasi kepentingan orang dewasa; (5) faktor sekolah, pihak sekolah mengabaikan tindakan bullying sehingga pelaku seperti mendapat penguatan terhadap perilakunya. Tindakan pengajar atau guru yang salah. Misalnya, guru berkata kasar kepada siswa, guru kurang memperhatikan kondisi anak baik dalam sosial ekonomi maupun dalam prestasi siswa. 
Adapun faktor-faktor yang mempengaruhi terjadinya bullying menurut Astuti (2008) adalah:

(1) Perbedaan kelas ekonomi, agama, gender, etnisitas atau rasisme, pada dasarnya perbedaan terlebih jika perbedaan tersebut bersifat ekstrim, individu satu kelompok, jika tidak terdapat toleransi oleh anggota kelompok tersebut, maka dapat menjadi penyebab bullying;

(2) Senioritas. Perilaku bullying seringkali justru diperluas oleh siswa sendiri sebagai kejadian yang bersifat lazim. Pelajar yang akan menjadi senior menginginkan suatu tradisi untuk melanjutkan dan menunjukkan kekuasaan, penyaluran dendam, iri hati atau mencari popularitas;

(3) Tradisi senioritas. Senioritas yang salah diartikan dan dijadikan kesempatan atau alasan untuk memelakukan bullying junior tidak berhenti dalam suatu periode saja. Hal ini tidak jarang menjadi peraturan tidak tertulis yang diwariskan secara turun menurun kepada tingkatan berikutnya;

(4) Keluarga yang tidak rukun; Kompleksitas masalah keluarga seperti ketidakhadiran ayah dan ibu, menderita depresi, kurangnya komunikasi antara orang tua dan anak, perceraian atau ketidakharmonisan orang tua dan ketidakmampuan sosial ekonomi merupakan penyebab tindakan bullying yang signifikan;

(5) Situasi sekolah yang tidak harmonis atau diskriminatif. Bullying juga dapat terjadi jika pengawasan dan bimbingan etika dari para guru rendah, sekolah dengan kedisiplinan yang sangat kaku, bimbingan yang tidak layak dan peraturan yang tidak konsisten dapat memancing munculnya perilaku bullying;

(6) Karakter individu atau kelompok seperti dendam dan iri hati. Hal ini karena mereka diperlakukan kasar dan dipermalukan sehingga pelaku menyimpan dendam dan kejengkelan yang akan dilampiaskan kepada orang yang lebih lemah atau junior pada saat menjadi senior. Adanya semangat ingin menguasai korban dengan kekuasaan fisik dan daya tarik seksual, yaitu keinginan untuk memperlihatkan kekuatan yang dimiliki sehingga korban tidak berani melawannya, untuk meningkatkan popularitas pelaku dikalangan teman sepermainan (peers), yaitu keinginan untuk menunjukkan eksistensi diri, mencari perhatian dan ingin terkenal;

(7) Persepsi nilai yang salah atas perilaku korban, korban seringkali merasa dirinya memang pantas untuk diperlakukan demikian, sehingga korban hanya mendiamkan hal tersebut terjadi berulang kali padanya.

Simbolon (2012), mengatakan faktor penyebab terjadinya bullying yaitu terdapat faktor internal dan eksternal. Sebagai faktor internal adalah karakteristik kepribadian, kekerasan yang dialami sebagai pengalaman masa lalu, sikap keluarga yang memanjakan anak sehingga tidak membentuk kepribadian yang matang. Sedangkan faktor eksternal yang menyebabkan kekerasan adalah lingkungan dan budaya perbedaan etnis, resistensi terhadap tekanan kelompok, perbedaan keadaan fisik, masuk di sekolah yang baru, latar belakang sosial ekonomi, dan pengalaman masa lalu.

Berdasarkan penjelasan di atas faktor-faktor penyebab bullying yaitu faktor keluarga, sekolah, media masa, teman sebaya, lingkungan sosial, karakter individu, senioritas, tradisi senioritas, dan perbedaan kelas ekonomi, agama, gender, etnisitas atau rasisme, serta persepsi nilai yang salah atas perilaku korban.

Menurut Coloroso (2007), ciri-ciri seseorang yang menjadi korban bullying antara lain anak baru di suatu lingkungan, anak termuda di sekolah, anak penurut, anak yang dianggap perilakunya mengganggu orang lain, anak yang tidak mau berkelahi dan lebih suka menyelesaikan konflik tanpa kekerasan, anak yang pemalu, menyembunyikan perasaannya, pendiam atau tidak mau menarik perhatian orang lain, penggugup, dan peka, anak miskin atau kaya, anak yang memiliki etnis/agama yang minoritas dan organisasi gender atau seksual yang berbeda, anak yang kurus atau gemuk, pendek atau jangkung, anak yang memakai kacamata atau kawat gigi, anak yang berjerawat atau memiliki masalah kondisi kulit lainnya, anak yang memiliki ciri fisik yang berbeda dengan mayoritas anak lainnya, anak dengan ketidakcakapan mental atau fisik.

Anak-anak seperti ini biasanya dua atau tiga kali lebih sering ditindas daripada anak-anak lain karena mereka memiliki ketidakcakapan mental yang nyata sehingga menyediakan dalih bagi sang pelaku (kekurangan yang dimiliki korban menjadi materi ejekan atau lelucon), anak yang berada di sekitar pelaku bullying. Mereka berpotensi untuk dikenai tindakan bullying karena pelaku sedang ingin menyerang siapapun di tempat itu dan pada saat itu juga.

Coloroso (2007), mengatakan apabila anak menjadi korban bullying, anak tidak akan memberitahukan kepada orang lain secara terus terang. Mereka mempunyai alasan untuk tidak memberitahukan masalah itu. Terdapat beberapa alasan anak tidak mau berterus terang, diantaranya 
merasa malu karena pernah ditindas, takut akan aksi balas dendam kalau orang dewasa diberitahu, mereka berpikir tidak ada orang yang dapat menolong mereka dan mereka tidak berpikir kalau ada orang yang akan menolong.

Stephenson dan Smith (dalam Trevi, 2012) mengatakan, ada tiga ciri-ciri korban bullying. Pertama, korban mempunyai sifat cemas serta self esteem dan kepercayaan diri yang rendah. Mereka selalu merasa dirinya lemah dan tidak berdaya serta tidak dapat berbuat apa-apa untuk menjaga diri. Kedua, korban yang proaktif mempunyai sifat yang lebih kuat secara fisik dan lebih aktif dibandingkan korban yang pasif.

Olweus (dalam Djuwita, 2006), menjelaskan mereka mempunyai masalah terhadap daya konsentrasinya. Mereka cenderung menciptakan suasana yang tidak nyaman serta memprofokasi teman-temannya untuk melakukan bullying terhadap orang yang lemah. Olweus (dalam Trevi, 2012), menyatakan satu dari lima korban adalah yang bersifat pro-aktif.

Ketiga, korban yang diprovokasi juga cenderung melakukan tindakan bullying. Perry (dalam Trevi, 2012), menemukan bahwa hal yang paling ekstrim dari korban adalah ketika mereka melakukan tindakan agresif, dibully oleh anak yang lebih kuat, lalu menjadi pelaku bullying terhadap anak yang lebih lemah.

Coloroso (2007) mengatakan, korban bullying merupakan pihak yang tidak mampu membela atau mempertahankan dirinya karena lemah secara fisik atau mental ketika mendapatkan perlakuan agresif dan manipulatif secara berulang-ulang.

Menurut Susanto (2010), ciri-ciri perilaku korban bullying adalah: Pertama, secara akademis, korban terlihat lebih tidak cerdas dari orang yang tidak menjadi koban bullying atau sebaliknya. Kedua, secara sosial, korban terlihat lebih memiliki hubungan yang erat dengan orang tua mereka. Ketiga, secara mental atau perasaan, korban melihat diri mereka sendiri sebagai orang yang bodoh dan tidak berharga. Kepercayaan diri mereka rendah dan tingkat kecemasan sosial mereka tinggi. Keempat, secara fisik, korban adalah orang yang lemah, korban laki-laki lebih sering mendapatkan siksaan secara langsung, misalnya bullying fisik.

Dibandingkan korban laki-laki, korban perempuan lebih sering mendapatkan siksaan secara langsung, misalnya melalui kata-kata atau bullying verbal. Kelima, secara antarperorangan, walaupun korban sangat menginginkan penerimaan secara sosial, mereka jarang untuk memulai kegiatan-kegiatan yang menjurus ke arah sosial. Anak korban bullying kurang diperhatikan oleh pembina karena korban tidak bersikap aktif dalam sebuah aktivitas.

Sementara itu menurut Lestari (2016), beberapa ciri-ciri perilaku korban bullying adalah: Pertama pemalu, pendiam, penyendiri. Kemudian kedua, mendadak menjadi penyendiri atau pendiam. Ketiga, sering tidak masuk sekolah dengan alasan yang tidak jelas. Keempat, berperilaku aneh atau tidak biasa (marah tanpa sebab, mencoret-coret, dan sebagainya). Kelima, untuk membalas dendam korban akan menjadi pelaku bullying agar ingin dipuja kelompok dan menarik perhatian orang lain.

Sullivan (dalam Retno, 2008) membeberkan beberapa ciri-ciri perilaku korban bullying yang terlihat dan dapat diidentifikasi mereka mengalami bullying di sekolah, diantaranya, pertama rasa malas bersekolah sehingga sering membolos atau terlambat berangkat ke sekolah. Kedua menunjukkan gejala kekhawatiran sehingga ia sering mengigau, pusing, panas, sakit perut, terutama terjadi saat pagi hari sebelum berangkat ke sekolah. Ketiga, ketika pulang ke rumah baju kotor bahkan rusak. Keempat, menunjukkan ketidaksabaran dan meminta sejumlah uang. Kelima, perilaku yang mencurigakan, seperti marah, risau dan risau. Keenam, berbisik dan menolak mengatakan apapun saat ditanya. Ketujuh, kemarahan kepada orang tua tanpa alasan yang jelas. Kedelapan, terlihat cemas, sedih, depresi, mengancam bahkan melakukan bunuh diri. Kesembilan, menghindari orang tua bila diajak bicara maupun ditanya. Kesepuluh mulai mengerjakan sesuatu yang tidak biasanya mereka lakukan.

Salah satu dampak dari bullying yang paling jelas terlihat adalah terganggunya kesehatan fisik. Beberapa dampak fisik yang biasanya timbul pada korban adalah sakit kepala, sakit tenggorokan, flu, bibir pecah-pecah dan nyeri di bagian dada. Bahkan dalam kasus-kasus yang ekstrim, dampak fisik ini bisa mengakibatkan kematian.

Dampak lain yang kurang terlihat, namun berefek panjang adalah menurunnya kesejahteraan psikologis (psychological well-being) dan penyesuaian sosial yang buruk. Riauskina, dkk (dalam Trevi, 2012), mengatakan ketika anak mengalami bullying, korban merasakan banyak emosi negatif (marah, dendam, kesal, cemas, tertekan, takut, malu, sedih, tidak nyaman, terancam), namun tidak berdaya 
menghadapinya. Dalam jangka panjang emosi-emosi ini dapat berujung pada munculnya perasaan rendah diri bahwa dirinya tidak berharga.

Menurut Yayasan Kesejahteraan Anak Indonesia (dalam Huraerah, 2018), tindakan kekerasan berdampak serius terhadap kehidupan seseorang, seperti cacat tubuh permanen, kegagalan belajar, gangguan emosional bahkan dapat menjurus pada gangguan kepribadian, konsep diri yang negatif, ketidakmampuan mempercayai dan mencintai orang lain, pasif dan menarik diri dari lingkungan, takut membina hubungan baru dengan orang lain, menjadi penganiaya ketika dewasa, agresif dan kadangkadang melakukan tindakan kriminal, menggunakan obat-obatan, dan kematian.

Craig dan Pepler (2007), mengatakan, bullying menimbulkan dampak yang merugikan, tidak hanya bagi korban tetapi juga bagi pelakunya. Sementara itu, menurut Peterson (dalam Berthold dan Hoover, 2000), bullying akan mempengaruhi self esteem korban dan hal tersebut merupakan pengaruh yang ditimbulkan dari pengaruh jangka panjang.

Mereka sebagai korban bullying sering mengalami ketakutan untuk sekolah dan menjadi tidak percaya diri, merasa tidak nyaman, dan tidak bahagia. Aksi bullying menyebabkan seseorang menjadi terisolasi dari kelompok sebaya (Setiawan, 2008).

\section{METODE PENELITIAN}

Penelitian ini menggunakan pendekatan kualitatif deskriptif untuk meninjau bagaimana strategi yang dijalankan oleh SMP Negeri 85 Pondok Labu, Jakarta dalam mempersuasi siswa sebagai upaya pencegahan bullying. Penelitian kualitatif menurut Sugiyono (2014) adalah metode penelitian yang berlandaskan pada paradigma postpositivisme, digunakan untuk meneliti pada kondisi obyek yang alamiah, (sebagai lawannya adalah eksperimen) dimana peneliti adalah instrumen kunci. Teknik pengumpulan data dilakukan secara triangulasi (gabungan), analisis data bersifat induktif/kualitatif dan hasil penelitian lebih menekankan makna dari pada generalisasi.

Penelitian kualitatif yang dilakukan pada penelitian ini ditempuh dengan dua cara yaitu Focus Group Discussion (FGD) dan wawancara mendalam (in depth interview). Narasumber pada FGD sebanyak empat orang yaitu kepala sekolah, wakil kepala sekolah bidang kesiswaan, guru bimbingan konselingdan guru yang merupakan Quality Control di sekolah tersebut. Sedangkan narasumber untuk wawancara mendalam adalah dua orang siswa yang mewakili pihak yang merupakan sasaran strategi. Pemilihan narasumber dilakukan dengan teknik purposif yang didasarkan pada pertimbanganpertimbangan tertentu, antara lain pihak sekolah yang berkompeten dalam penyusunan strategi mengenai pencegahan bullying. Selain itu dari sisi penerima pesan, diambil siswa yang paham akan strategi yang dijalankan oleh pihak sekolah.

Panduan untuk wawancara digunakan agar pertanyaan yang diajukan sesuai dengan konsep yang telah ditentukan sebelumnya. Teknis wawancara dilakukan secara tatap muka langsung pada saat FGD dan juga wawancara mendalam melalui Whatsapp call dan video call kepada siswa.

Analisis data dilakukan dengan menelaah seluruh data dari hasil FGD terhadap empat narasumber dan hasil wawawncara dua orang siswa. Selain itu juga pengamatan yang diperoleh dari berbagai sumber. Setelah itu dilakukan reduksi data dan penyusunan data menurut kategori yang telah disusun dalam kerangka pemikiran. Tahapan terakhir adalah melakukan intepretasi data.

\section{HASIL PENELITIAN}

Program pencegahan bullying di SMP Negeri 85 Jakarta mengacu pada program yang dibuat oleh Dinas Pendidikan Jakarta Selatan dan Kapolsek Cilandak. Jadi program ini sifatnya top down, pihak sekolah hanya mengaplikasikan program tersebut. Program ini disosialisasikan dari dinas kemudian ke suku dinas. Dari suku dinas disampaikan ke kepala-kepala sekolah untuk menyikapinya dan menangani bullying serta tawuran. Pemerintah DKI Jakarta lalu mengadakan deklarasi anti bullying dan tawuran.

Program ini pertama kali dilaksanakan oleh walikota dengan mengadakan deklarasi, dihadiri perwakilan dari sekolah-sekolah. Pada deklarasi itu, para pelajar dikumpulkan bersama Kepala Dinas, Walikota dan Polres. Deklarasi tersebut kemudian disikapi oleh kecamatan dengan mengadakan deklarasi tingkat kecamatan. Dihadiri oleh Kapolsek, Koramil, Lurah, dan pihak sekolah (Wawancara data primer, 2020).

Deklarasi yang diadakan di SMP Negeri 85 Jakarta dilakukan setiap satu semester. Pada deklarasi, kepada para siswa juga disosialisasikan aturan, siswa yang melanggar poin tertentu seperti bullying, 
tawuran, pornografi, akan dikembalikan ke orang tua. Hal itu disampaikan Kepala Sekolah SMP Negeri 85:

"Jika dilihat programnya, yang pertama mengacu kepada peraturan yang dibuat oleh Dinas Pendidikan dan Kapolsek Cilandak, lalu ke suku dinas kemudian dijabarkan di sekolah. Yang disebut bullying itu, termasuk misalnya mereka bercanda, becanda sekali mungkin tidak apa-apa, kemudian becanda kedua, ketiga itu sudah mulai terjadi bullying, bisa verbal atau non verbal

Menurut narasumber yang lain:

Inti dari bullying adalah rasa gerah seorang anak sehingga mereka tidak kondusif lagi untuk belajar, tidak merasa tenang belajar, bahkan juga bergaul agak sempit. Sehingga SMP Negeri 85 merasa penting sekali untuk mendeteksi. Sebagai contoh, apa anak ini terkena bullying atau tidak, bila sedang istirahat anak ini tampak diam, ada apa ini? Apakah diamnya anak ini karena sedang merenungi pelajaran atau efek dari bullying? Misalnya, anak ini tidak punya masalah tapi sering diganggu, gangguan itu banyak, gangguan terhadap fisik, ada gangguan juga terhadap mental, terkadang diisengin"

Sesuai yang disampaikan oleh Ken Rigby (2008), "Bullying is the systematic abuse of power in interpersonal relationship". Bullying adalah suatu bentuk penyalahgunaan kekuatan atau kekuasaan secara sistematis dalam hubungan antarperorangan. "Kekuatan" atau "Kekuasaan" adalah orang-orang yang memungkinkan untuk melakukan tindakan bullying karena adanya suatu wewenang atau dapat juga disebut dengan orang yang berkuasa.

Dampak dari bullying terhadap korban berefek panjang yakni menurunnya kesejahteraan psikologis (psychological well-being) dan penyesuaian sosial yang buruk. Riauskina, dkk (dalam Trevi, 2012) mengatakan, ketika mengalami bullying, korban merasakan banyak emosi negatif (marah, dendam, kesal, cemas, tertekan, takut, malu, sedih, tidak nyaman, terancam), namun tidak berdaya menghadapinya. Dalam jangka panjang emosi-emosi ini dapat berujung pada munculnya perasaan rendah diri.

Seperti yang disampaikan oleh Juwita (dalam Astuti, 2008), dampak lain yang kurang terlihat namun berefek jangka panjang adalah menurunnya kesejahteraan psikologis (psychological well-being) karena korban merasakan emosi negatif seperti marah, dendam, kesal, tertekan, takut, malu, dan sedih. Dampak paling ekstrim dari bullying adalah gangguan psikologis, seperti cemas berlebihan, selalu merasa takut, trauma, serta depresi hingga ingin bunuh diri.

Pasca deklarasi, SMP Negeri 85 Jakarta membentuk Jaringan Komunikasi (Jarkom) anti tawuran dan bullying. Jarkom terdiri dari anggota aktif mulai dari kepala sekolah negeri atau swasta mulai dari tingkat SD, SMP SLTA, SMK dan pihak kelurahan setempat. Fungsi Jarkom adalah menyisir tempattempat potensial untuk tawuran, bullying, penyalahgunaan narkoba dan tempat mabuk-mabukan. Patroli dilakukan Jarkom bersama polisi, pihak kelurahan dan masyarakat.

Pada saat berpatroli, para anggota Jarkom tidak mengenakan pakaian seragam. Hal ini dilakukan agar para siswa tidak mengetahui keberadaan tim sekolah dan para anggota Jarkom. Masyarakat umum juga dilibatkan dalam pemantauan tawuran, bullying dan narkoba (Wawancara data primer, 2020).

Patroli dilakukan setiap hari, terutama pada hari-hari terjadinya tawuran dan bullying yaitu setiap hari Jumat sore. Hal ini terjadi karena pelajar SMP, SMK, SMA, merasa hari Jumat adalah hari terakhir belajar dalam seminggu. Untuk itu dilakukan patrol Jarkom setiap Jumat sore sampai malam. Jarkom cukup efektif sebagai media komunikasi antara berbagai pihak (Wawancara data primer, 2020).

Berikut ini adalah penjelasan unsur-unsur dalam Komunikasi Persuasif yang dilakukan dalam penelitian ini. Pertama Persuader yaitu orang dan atau sekelompok orang yang menyampaikan pesan dengan tujuan untuk mempengaruhi sikap, pendapat dan perilaku orang lain, baik secara verbal maupun nonverbal.

Dalam penelitian ini Persuader adalah pihak sekolah yang aktif memberikan pengarahan dan sosialisasi melalui deklarasi. Wali kelas juga memiliki cara tersendiri, misalnya ketika hari Jumat atau hari-hari tertentu menyisipkan pesan-pesan kepada para siswa. Wali kelas dianggap persuader yang baik, karena mengetahui kondisi para siswanya. Wali kelas bekerja sama dengan bagian konseling menganalisis data orang tua murid. Hal ini penting untuk melihat korelasi perilaku siswa. Sebagai sekolah favorit, SMP Negeri 85 Jakarta mempersuasi murid dengan cara sosialisasi program kepada 
siswa. Pada saat upacara bendera dibacakan amanat dan janji siswa untuk tidak melakukan bullying dan tawuran serta janji menjunjung tinggi nama baik sekolah.

Unsur kedua adalah Persuadee yaitu orang dan atau kelompok orang yang menjadi tujuan pesan dari persuader/komunikator baik secara verbal maupun nonverbal. Persuadee pada penelitian ini adalah para siswa SMP Negeri 85 Jakarta. Unsur ketiga adalah Persepsi. Persepsi persuadee terhadap persuader dan pesan yang disampaikannya akan menentukan efektif tidaknya komunikasi persuasif yang terjadi. Dalam hal ini, siswa merasa senang dan nyaman dengan program yang disosialisasikan pihak sekolah. Meskipun program tersebut dicanangkan Dinas Pendidikan, namun penanganan tawuran dan bullying yang dilakukan oleh Polsek Cilandak didukung sepenuhnya oleh pihak sekolah.

Tidak hanya para siswa yang merasa senang tetapi juga orang tua murid dan tidak kuatir anaknya belajar di SMP Negeri 85 Jakarta. Mereka tidak khawatir anaknya yang belajar di SMP Negeri 85 Jakarta terjerumus tawuran, bullying atau kenakalan remaja lainnya. Selain itu para guru juga menjadi bersemangat dalam mengajar dan tidak terbebani hal-hal yang kurang produktif.

Unsur keempat adalah Pesan Persuasif. Menurut Littlejohn dalam Ritonga (2005), pesan persuasif dipandang sebagai usaha sadar untuk mengubah pikiran dan tindakan dengan memanipulasi motif-motif ke arah tujuan yang telah ditetapkan. Makna memanipulasi dalam pernyataan tersebut bukanlah mengurangi atau menambah fakta sesuai konteksnya, tetapi memanfaatkan faktum-faktum yang berkaitan dengan motif-motif khalayak sasaran, sehingga tergerak untuk mengikuti maksud pesan yang disampaikan kepadanya. Pesan persuasif itu berbentuk deklarasi yang diucapkan saat upacara sebelum mulai pelajaran.

Unsur yang kelima Saluran Persuasif, merupakan perantara ketika seorang persuadee mengoperkan kembali pesan yang berasal dari sumber awal untuk tujuan akhir. Saluran (channel) digunakan oleh persuader untuk berkomunikasi dengan berbagai orang, secara formal maupun nonformal, secara tatap muka (face to face communication) ataupun bermedia (mediated communication). Pada penelitian ini pihak sekolah menggunakan saluran deklarasi atau amanat yang di lakukan setiap semester melalui forum upacara bendera. Selain itu para wali kelas juga menyampaikan pesan tersebut secara tatap muka sebelum kelas berlangsung.

SMP Negeri 85 Jakarta berusaha keras dalam menanggulangi masalah kenakalan remaja seperti bullying, tawuran dan narkoba. Hal ini dilakukan karena pihak sekolah menjaga nama baiknya supaya tidak turun predikatnya sebagai sekolah favorit. Sekolah ini memiliki gambaran yang baik di mata masyarakat. Jadi orang tua pun tidak merasa khawatir memasukkan anaknya di sekolah tersebut.

Guru, kepala sekolah, staf administrasi, dan para siswa aktif memelihara keharmonisan sekolah sehingga tidak terjadi bullying yang parah. Hal ini menurut De Vito (2011) merupakan prinsip Partisipasi Khalayak. Khalayak disini merupakan sasaran persuasi. Aktivitas komunikasi persuasif ini akan lebih efektif apabila khalayak turut berpartisipasi dalam proses komunikasi. Persuasi bersifat transaksional, pembicara dan pendengar saling terlibat. Suatu proses persuasi dikatakan berhasil apabila khalayak berpartisipasi secara aktif di dalamnya. Dengan mengacu pada pandangan De Vito tersebut, terlihat bahwa pihak sekolah bisa bekerjasama dengan siswa, sehingga hasil persuasif bisa efektif dan menyenangkan bagi siswa, orang tua dan guru.

Penelitian ini menguatkan penelitian yang sebelumnya dilakukan oleh Dewi, Hasan, Mahmud (2016) tentang perilaku bullying di SD Negeri Unggul Lampeuneurut, Aceh Besar yang menunjukkan bahwa lebih dari 50\% siswa pernah mengalami kejadian bullying fisik di sekolah, dan 37\% dari 25 siswa yang menjawab tidak pernah mengalami kejadian bullying fisik, serta yang mengalami kejadian bullying non-fisik pada mereka.

Prinsip Besaran Perubahan bisa dikatakan bahwa semakin besar dan semakin penting perubahan yang diinginkan oleh persuader, maka semakin besar tantangan dan tugas untuk mencapai tujuan persuasi. Semakin besar perubahan yang diinginkan, semakin banyak pula waktu yang dibutuhkan untuk perubahan tersebut. Sehingga, persuasi diarahkan untuk melakukan perubahan kecil atau sedikit demi sedikit terlebih dahulu dan diperlukan untuk periode yang cukup lama.

Penelitian yang dilakukan oleh Zakiyah, Fedryansyah, Gutama (2018) berjudul Dampak bullying pada Tugas Perkembangan Remaja Korban bullying, menunjukkan bullying memengaruhi tugas perkembangan remaja korban bullying. Namun terdapat faktor yang dapat menghambat dampak tersebut, yaitu dukungan sosial dan strategi coping. Maka dari itu diperlukan program anti-bullying yang melibatkan kerja sama antara guru, orang tua, dan siswa dalam menciptakan lingkungan yang suportif sehingga korban merasa nyaman untuk mencari bantuan kepada lingkungannya. Untuk itulah 
perlu dilakukan strategi persuasi yang dilakukan oleh sekolah untuk memengaruhi siswanya untuk mencegah bullying di SMP Negeri 85 Jakarta.

Proses Komunikasi Persuasif dilakukan sebagai upaya memengaruhi opini, pendapat, sikap atau perilaku seseorang. Pada SMP Negeri 85 Jakarta, walaupun bullying bagi sebagian orang masih termasuk hal-hal yang wajar, namun tidak diperbolehkan terjadi di sekolah ini. Misalkan sekali dilakukan dan setelah itu tidak ada masalah. Namun bila korban sudah merasa terganggu, maka sekolah harus mengambil tindakan.

Upaya yang dilakukan sekolah, salah satunya adalah dengan pembiasaan. Misalnya bapak atau ibu guru sekitar lima menit memberikan nasihat sesuai dengan kondisi yang terjadi dan membenahi sikap sebelum pelajaran dimulai. Dan di akhir pelajaran guru mengaitkan materi pelajaran dengan pesanpesan persuasi yang ingin disampaikan. Dengan cara seperti itu diharapkan siswa akan teringat terus pesan yang disampaikan. Artinya setiap perubahan kecil akan menjadi suatu prestasi bagi sekolah dan murid-muridnya dalam strategi penanganan bullying ini.

\section{KESIMPULAN}

Strategi persuasi yang dilakukan oleh pihak sekolah SMP Negeri 85 Jakarta dalam pencegahan bullying cukup efektif. Bersama-sama dengan Dinas Pendidikan dan Kapolsek Cilandak dan beberapa pihak melakukan deklarasi anti bullying dan tawuran. Deklarasi tersebut kemudian diturunkan oleh pihak sekolah kepada siswa untuk juga melakukan deklarasi di tingkat sekolah. Program yang dicanangkan ini bersifat top down, dari Dinas Pendidikan kemudian diturunkan ke suku dinas. Dari suku dinas disampaikan ke kepala-kepala sekolah untuk melaksanakan program tersebut. Kemudian kerjasama juga dilakukan dengan Kapolsek Cilandak yang merancang tema mengenai sosialisasi pencegahan tawuran dan bullying.

Tanggapan dari siswa SMPN 85 Jakarta yang mendapat program pencegahan bullying, mereka merasa senang, nyaman dan bisa belajar dengan tenang. Hal ini berdampak kepada peminatan calon siswa yang akan masuk ke SMP Negeri 85 Jakarta. Calon siswa dan orang tua memiliki gambaran yang baik mengenai sekolah ini. Jadi orang tua pun tidak merasa khawatir memasukkan anaknya di sekolah tersebut, sehingga wajar jika sekolah ini mendapat predikat sebagai sekolah favorit.

\section{DAFTAR PUSTAKA}

Astuti, P.R (2008). Meredam bullying: 3 Cara efektifmengatasi kekerasan pada anak. Jakarta. UI Press. Barata, A.A. (2003). Dasar-Dasar Pelayanan Prima. Jakarta: PT. Gramedia Pustaka.

Berthold, K. A., Hoover, J. H. (2000). "Correlates of Bullying and Victimization among Intermediate Students in the Midwestern USA". Sage Publication Volume 21, No. 1.

Black, J. (2007). Using bullying incident density to evaluate the olweus bullying prevention programme. School psychology international.

Coloroso, B (2007). The Bully, the bullied, and the bystander. New York: HarperCollins.

Craig. Wendy, Pepler. Debra, Julie Blais. (2007). School Psychology International http://spi.sagepub.com/content/28/4/465. DOI: 10.1177/0143034307084136.

Dewi, N., Hasan, H., \& AR, M. (2016). Perilaku Bullying yang Terjadi di SD Negeri Unggul Lampeuneurut Aceh Besar. Jurnal Ilmiah Pendidikan Guru Sekolah Dasar, 1, 37-45.

De Vito, Joseph A. (2011). Komunikasi Antarmanusia. Tangerang Selatan: KARISMA Publishing Group.

Djuwita, R. (2006). Masalah Tersembunyi dalam Dunia Pendidikan di Indonesia. Workshop Bullying. 29 April. Jakarta: Universitas Indonesia (UI) http//www.google.com/bullying/WEBSITEDirektorat Pembinaan Sekolah Luar Biasa.htm14/05/2007. E

Efendi, F. (2019). Memahami Fenomena “Bullying” di Kalangan Remaja Indonesia. Unair News. Diakses pada 30 Maret 2020. http://news.unair.ac.id/2019/09/02/memahami-fenomenabullying-di- kalangan-remaja-indonesia/

Gunadha, R \& Aditya, R. (2020). Remaja 17 tahun Bunuh Diri karena di-bully pelakunya datang ke pemakaman. Diakses pada $30 \quad$ Maret 2020. https://jatim.suara.com/read/2020/03/06/163007/ngaku-alami-perund ungan-siswi-smp-dikediri-depresi-dan-ingin-bunuh-diri

Huraerah. A. (2018). Kekerasan Terhadap Anak. Jakarta: Penerbit Nuansa 
Iswinarno, C. (2020). Ngaku Alami Perundungan, Siswi SMP di Kediri Depresi dan Ingin Bunuh Diri. Diakses pada 30 Maret 2020. https://jatim.suara.com/read/2020/03/06/163007/ngaku-alamiperund ungan-siswi-smp-di-kediri-depresi-dan-ingin-bunuh-diri

Jefrizal. (2020). Korban Bully dan Dianiaya, Murid SD Depresi Berat... Takut Lihat $\quad$ Orang Berseragam Sekolah. Diakses pada 30 Maret 2020. https://infojambi.com/korban-bully-dandianiaya-murid-sd-depresi- berat-takut-lihat-orang-berseragam-sekolah/

Lestari, W.S. (2016) Analisis Faktor-faktor penyebab bullying di kalangan peserta didik, Social science educational journal.3(2)

Parsons, L. (2009). Bullied Teacher Bullied Student : mengenali budaya kekerasan disekolah anda dan mengatasinya. Jakarta: PT Grasindo.

Prasetyo, A. B. E. (2011). Bullying di sekolah dan dampaknya bagi masa depan anak. El Tarbawi, 4(1), 19-26.

Rakhmat, J. (2008). Psikologi Komunikasi. Bandung: Remaja Rosdakarya.

Retno, P. A. (2008). Meredam bullying 3 cara efektif mengatasi kekerasan pada anak, Jakarta: PT Grasindo.

Rigby Ken (2008), Children and bullying. United Kingdom: Blackwell publishing

Ritonga, J. 2005. Tipologi Pesan Persuasif. Jakarta: PT. Indeks.

Riyanto \& Mahfud, Waryani Fajar \& Mokhamad. 2012. Komunikasi Islam I (Perspektif IntegrasiInterkoneksi). Yogyakarta: Galuh Patria.

Santoso, B. (2020). Diduga Jadi Korban Bullying, Anak SD di Jambi Depresi dan Masuk Rumah Sakit. Diakses pada 30 Maret 2020.

Setiawan. B. (2008). Agenda Pendidikan Nasional. Yogyakarta: Ar-ruzz media.

Severin \& Tankard, Werner \& James. (2007). Teori Komunikasi: Sejarah, Metode, dan Terapan di dalam Media Massa. Jakarta: Kencana.

Simbolon, M. (2012). Perilaku Bullying pada mahasiswia berasrama. Jurnal Psikologi Universitas Indonesia - Advent Bandung. 39(2), 223-234.

Sugiyono. (2014). Metode Penelitian Kualitatif Kuantitatif dan R\&D. Bandung: Alfabeta.

Sumirat, Suryana, Soleh Asep. (2014). Komunikasi Persuasif. Banten: Universitas Terbuka.

Susanto, Dwi Wulandari. (2010). Fenomena Korban Perilaku Bullying pada Remaja dalam Dunia Pendidikan. Semarang: Fakultas Psikologi Unika Soegijapranata.

Trevi Trevi, Winanti Siwi Respati. (2012). Sikap Siswa Kelas X Smk Y Tangerang Terhadap Bullying. Jurnal Psikologi, Media Ilmiah Psikologi. 10(1)

Zakiyah, E. Z., Fedryansyah, M., \& Gutama, A. S. (2018). Dampak bullying pada tugas perkembangan remaja korban bullying. Focus: Jurnal Pekerjaan Sosial, 1(3), 265-279. 